\title{
Multiple perspectives on imprisonment in Europe
}

\author{
Dr. Linda Kjor Minke; Dr. Marguerite Schinkel; Dr. Karin \\ Beijersbergen; Dr. Cristina Damboeanu, Mgr. Lukáš Dirga; \\ Prof. Anja Dirkzwager; Prof. Yvonne Jewkes; Dr. Victoria Knight, \\ Dr. Dominique Moran; Dr. Hanneke Palmen; Dr. Valentina \\ Pricopie; PhD Student Fabio Tartarini; Dr. Philippa Tomczak; \\ Dr. Jennifer Turner; PhD Student An-Sofie Vanhouche; \\ Prof. Azrini Wahidin ${ }^{1}$
}

\begin{abstract}
There are currently over 1.6 million prisoners in Europe and conditions in European prisons vary widely. The European Society of Criminology's Working Group on Prison Life and the Effects of Imprisonment was established in 2010. The Working Group consists of scholars from over 20 countries who aim to encourage prison research in Europe. These academics meet twice per year to discuss a variety of prison-related topics. The current article reviews some of the contributions to the Working Group's meeting in Denmark in April 2016. It describes a broad selection of contemporary research on various aspects of the unique prison contexts found in different European countries. The contributions highlight a range of opportunities to improve conditions of confinement and to reduce recidivism after release.
\end{abstract}

\section{Introduction}

In most European countries, imprisonment is the most severe governmental sanction that can be imposed on criminal offenders. The most recent figures indicate that there are just over 1.6 million prisoners in Europe, of which over a third, are incarcerated in the Russian Federation (International Centre for Prison Studies, 2016). ${ }^{2}$ Therefore, many individuals experience imprisonment and its consequences, either directly (prisoners) or indirectly (families of prisoners). Conditions in European prisons vary widely. For example, the level of occupancy in the Netherlands is $77 \%$, while in France there is significant overcrowding, with prisons at $119 \%$ of capacity (International Centre for Prison Studies, 2016). ${ }^{3}$ Overcrowding is not the only measure of the conditions of confinement: prisons in different countries have very different regimes with regards to time in cell, activities 
on offer, levels of safety, length of sentence etc. As an illustration, the Nordic countries (Finland, Sweden, Norway) are considered to have 'exceptional' penal conditions due to comparatively low imprisonment rates and relatively humane prison conditions, and their prisons tend to be small and relatively well staffed (Pratt and Eriksson, 2013).

The composition of the prison population also differs between countries. For instance, in the Netherlands pre-trial detainees make up almost $40 \%$ of the prison population, compared to only $6.7 \%$ in Poland (International Centre for Prison Studies, 2016). ${ }^{4}$ In general, material conditions within remand centres are poor and more austere, and in most cases remand centres serve as static institutions of confinement and punishment with little investment in rehabilitation (Minke \& Smoyer, forthcoming). Finally, as famously noted by Wacquant (1999), foreign nationals are imprisoned disproportionally almost everywhere in Europe, but this ranges from $1 \%$ of the prison population in Romania to $73 \%$ in Switzerland (International Centre for Prison Studies, 2016). ${ }^{5}$

Prison life has attracted attention from scholars in sociology and criminology. Early research initially focussed on the social organization within prisons, describing prisons as "total institutions", emphasising the prison culture and the pains of imprisonment (Clemmer, 1958; Goffman, 1961; Sykes, 1958). Since then, also triggered by increasing imprisonment rates throughout the world, scientific interest has expanded. In 2010, the European Society of Criminology's Working Group on Prison Life and the Effects of Imprisonment was established (effectsofprisonlife.wordpress.com). In this working group scholars from over 20 different countries aim to stimulate prison research in Europe and to promote communication and collaboration between European prison researchers. These academics meet twice a year to discuss a variety of prison-related topics. This article brings together some of the contributions to its meeting in Denmark in April 2016. By combining these different perspectives on different regimes, it sheds a unique light on prison conditions in different parts in Europe. By providing these situated perspectives, we hope to enhance comparative debate across prison studies.

\section{Human rights and Czech prisons}

In this first contribution, Dirga explores the process of humanization of prison conditions in the Czech Republic. Since 1990, the Czech Republic (former Czechoslovakia) has been putting emphasis on transformation of the Czech prison system following the examples of advanced foreign prison models (The Czech Prison Service, 2005, 2014; The Ministry of Justice of the Czech Republic, 
2016). One of the major areas included in conceptual plans and set goals is the human rights issue and the related process of humanization. Although the process of humanization of the prison system has been one of the key topics of the Czech penal policy for a long time, there is only minimal attention given to it within prison research. ${ }^{6}$

Dirga's findings are based on ethnographic research conducted in Czech prisons, which included an analysis of key documents relating to the Czech prison system (written materials) and a field data collection focused on the perspectives of prison world key actors. As part of prison visits, he conducted 14 interviews with prison guards, 20 interviews with inmates, five interviews with representatives of prison management and five interviews with special educators and psychologists. This was complemented with approximately 70 hours of observation inside the prisons.

The analysis of data reveals relatively strong inconsistencies between (declaring) the implementation of the process of humanization at the level of written materials and at the level of real practice. In written materials, the emphasis on the implementation of the principles of humanization in the Czech prison system practice is noticeable. On a practical level, however, change is minimal according to those interviewed. Prison guards seem to be the biggest critics of the process of humanization of the Czech prison system. They judge negatively on both the philosophy of expansion of convicts' human rights and its practical implementation. Convicts see the process of humanization as "a magical incantation" that is only "on paper". In practice, however, there is no significant change. Special educators and psychologists concur. The respondents' statements show that the process of humanization of the Czech prison system has been conducted in the framework of formal policy rather than in the context of everyday practice behind the bars of Czech prisons.

\section{Prison life issues in Romania}

Romania has shown a similar gap between rhetoric and practice, but one that is even more pronounced. Pricopie focuses on the parliamentary debate in Romania from 2007-2015 where prison issues became omnipresent on the political agenda of the Romanian Members of Parliament and autonomous subjects of debate. Damboeanu argued that over the past ten years, Romania has adopted important prison reforms aimed at promoting a humane perspective of imprisonment congruent with the modern principles of European regulations. ${ }^{7}$ Yet, while figuring prominently in the official/ legal rhetoric, in practice these developments are less visible. As documented both by the CPT and the national Ombudsman - but also 
featuring in several European Court of Human Right convictions pronounced against Romania - overpopulation, bad hygiene conditions, lack of privacy and the limited opportunities for work and other socially valued activities are structural elements of incarceration in Romanian prisons. As a brief example, the level of prison overcrowding is currently around $150 \%$. Consequently, all but one prison operate over the designed capacity; and six actually incarcerate more than twice as many prisoners as the European standards admit. ${ }^{8}$

Poor conditions of confinement and their detrimental impact on human dignity may de-legitimize the prison regime and validate instead the prison subculture. Starting from this premise, Damboeanu interrogated how prisoners adapt to such difficult conditions and what role(s) prison subculture plays in tackling the deprivations they experience during imprisonment. A group of 18 prisoners incarcerated in a maximum security prison were interviewed face-to-face using a semistructured in-depth interviewing technique. The interviews covered several topics related to prisoners' experience of incarceration and were conducted in 2013 as part of a larger research project focused on the effects of imprisonment. The study concludes that: (1) Prisoners situate the experience of imprisonment at the interplay between the classical deprivations (Sykes, 2007 [1958]) and those derived from the perceived deficit of procedural justice in the official administration of everyday life in prison; (2) The poor prison conditions lead to the profound segmentation of prisoners along socioeconomic lines, which in turn increases the potential of prisoner-to-prisoner exploitation; (3) Prisoners make great use of subcultural norms to better handle their lives in prison, but also to conserve their pre-prison identities; this significantly dilutes the deterrent effects of imprisonment and contributes to the trivialization of the prison experience.

\section{Political protest and the prison experience}

In work touching on how poor conditions are resisted in another place and time, Wahidin examined the nature of political protest and the experiences of imprisonment from the perspective of Republican political female prisoners who were held at Armagh Goal prison from the 1970s through to the Good Friday Agreement in 1998 in Northern Ireland (Wahidin, 2014). Her work contextualises political protest, gendered violence and prison power and how the Republican female political prisoners found ways to subvert/ resist the power of the prison to punish. In response to the violence of incarceration the women employed forms of political protest such as the no wash protest where excrement and blood were appropriated by the women in Armagh gaol as a weapon against the penal institution. Menstrual blood, dirt and faeces were no longer merely marginal substances that 
must be hidden and sanitised, but weapons of protest. Incarceration was transformed into an arena for political resistance that served to challenge and disrupt the power of the state.

In the prison context, while the material conditions cannot completely determine resistance, they influence, shape, and even contort both the operation of power and resistance. Resistance here is understood as the collective assertion of the political status of prisoners, and by extension, the political character of the Conflict. It is argued that (a) escape, (b) the No Wash Protest and the Hunger Strikes, (c) violence and (d) the use of law have been key elements of that collective assertion. As Scott $(1985,299)$ has suggested, the parameters of resistance are also set, in part, by the institutions. It is not just simply that 'where there is power, there is resistance'. Rather, resistance and the exercise of power are mutually constitutive even though resistance 'occupies a position of exteriority in relation to power' (Foucault, 1990, 95). This challenges the tendency to present power and resistance as binary opposites. This challenge has also been focused on by Buntman $(2003,265)$, who suggests that power should be seen in its 'myriad of bodies' and 'ranges of operations'. She argues that 'the relationship between power and resistance is closer to a continuum than a relationship between opposites' (ibid, 267).

\section{Institutional responses to prison suicide}

In a contribution that examine institutional responses to occasions when a prisoner ends his/her life, Tomczak explored institutional responses to prison suicide in English and Welsh prisons. The previous peak rate of self-inflicted deaths occurred during 2002-3, at 1.5 per 1,000 prisoners, but then stabilised until 2013 (Ministry of Justice, 2016: 9). The rate then rose by $69 \%$ between April 2013 and 2014 (Ministry of Justice, 2014), and the 12 months ending April 2016 saw the highest rate of self-inflicted deaths in 13 years, with 100 such deaths (Ministry of Justice, 2016: 8-9). These dramatic increases have occurred despite recent strengthening of prison inspection, monitoring and regulation mechanisms. For example, 2008 saw the establishment of the Independent Advisory Panel and Ministerial Council on Deaths in Custody, and 2004 saw the expansion of the Prisons and Probation Ombudsman to investigate prison deaths. Such suicides form traumatic bereavements for prisoners' families and friends, affect fellow prisoners and custodial staff, leave prisons open to legal challenges and have a huge economic cost. It is also particularly important to research suicides occurring in closed penal institutions which have coercive powers over detainees. Liebling has studied the relationships between the quality of prison life and pris- 
on suicide (2004), but has not specifically considered responses to prison suicide, which have an important role in ensuring that lessons are learnt, and preventing future deaths and suffering nationally. Research in this area could also lead to sharing of good practice internationally.

The financial costs of prison suicide could be as high as $£ 300$ million for the 95 prison suicides between September 2014 and 2015 (Howard League, 2016). Prison suicides substantially drain the resources of not only prisons, but also health services that respond to and often treat casualties before their death, local authorities who have to hold inquests and police forces who investigate the deaths (Howard League, 2016). Following a prison suicide in England and Wales, there are three formal investigations, which contribute to these costs: by the Police, Coroner and Prison and Probation Ombudsman. These investigations are required by Article 2 of the European Convention on Human Rights (ECHR), which places a positive duty on states to effectively investigate any death at their hands. Whilst these investigations are ECHR compliant in that they are the state's own initiative, allow for public scrutiny, and allow the next of kin to participate, in their current form they are not capable of giving relatives the satisfaction of knowing that lessons have been learned which could save the lives of others. For example, there is no collation, analysis or central and searchable publication of narrative inquest verdicts from coroners, nor their Prevention of Future Death Reports, which are "left to gather dust away from public scrutiny and analysis" (Inquest, 2013: 6-8). As matters currently stand, at most the local institutions will learn the wider lessons from a narrative verdict, not those responsible for all institutions of detention nationally (Inquest, 2013: 6-8). In a similar vein, ombudsman reports are hugely detailed and often make numerous recommendations, but are primarily targeted at individual prisons and have no statutory basis (PPO, 2015).

Whilst Tomczak agrees that investment in suicide prevention and mental wellbeing is a good idea (Howard League, 2016), she argues that prevention efforts should be better informed by the findings of investigations into past deaths. The findings of inquest verdicts and ombudsman reports need to be better translated from their current place within reams of paper sent to individual prisons, into knowledge which actively informs national policy and practice and prevents future deaths. It is not enough to have investigatory bodies and investigations, the state must make sure that their work is effective and creates less harmful penal institutions. 


\section{Human Flourishing in prison?}

In an examination of the opposite of the pains of and reactions to poor prison conditions, Tartarini explored the ways in which prisons could provide an environment conducive to growth and Human Flourishing. Research has highlighted that in supportive and secure environments, captive individuals can significantly increase their well-being and feel more confident and motivated to pursue selfgrowth (see for example, Bilby, Caulfield, \& Ridley, 2013; Cox \& Gelsthorpe, 2009). However, this type of research is mostly sporadic and rarely the result of a systematic exploration of the psychosocial dynamics behind this process. Tartarini's $\mathrm{PhD}$ research aims to fill this gap and to explore how the process of $\mathrm{Hu}-$ man Flourishing takes place in prison over time, the factors which affect it, and the way prisoners define it in their daily lives (both inside and outside of prison).

The research fieldwork took place over 9 months in a local category B prison in England and consisted of two set of interviews: the first one $(\mathrm{N}=40)$ aimed at the identification of what prisoners define as a Human Flourishing as well as investigating the factors which can promote or hinder it; the second one $(\mathrm{N}=24)$, focussed on the changes in prisoners' definitions and 'levels' of Human Flourishing, and on the identification the factors involved in their process. The initial analysis of 20 interviews confirms the traditional vision of prisons as being mostly places of pain and suffering (see, Crewe, 2011; Goffman, 1961; Sykes, 1958), where Human Flourishing is unlikely. As indicated by one of the interviewees:

"In an environment like this, you are oppressed. I do not think you can reach full potential, not as set up as it is; because I do not think it gives you the opportunity to flourish in the correct way. It takes all the decisions away from you, it takes your identity away from you, and how can you flourish if you are just a prison number?" (Charles).

Prisoners' definitions of flourishing, more than being focussed on self-improvement and fulfilment, is about adaptation, resistance, and progression through the system. Human Flourishing in prison is, in most cases, the result of a survival reaction to the initial trauma of imprisonment and the draining experience of forced idleness and rumination. It is often associated with "keeping yourself to yourself" (i.e., avoid troubles or complying) or "keeping busy" (i.e., engaging in prison or in-cell activities). Flourishing is also about re-gaining a sense of identity and humanity, by engaging with and supporting other prisoners or just indulging in the few life pleasures still allowed in prison (e.g., purchase better quality toiletries, tea and coffee). A smaller number of interviewees identified flourishing with making constructive use of time to pursue their personal goals and aspirations, 
and preparing for release. Overall, these individuals report more positive emotions, experienced 'flow' in their daily activities (i.e. lose themselves in them), had more positive relationships, found meaning or purpose in their sentence, and engaged in more activities (see Seligman's PERMA theory of well-being, 2011).

By looking at prisoners' development through time it is possible to see how the interplay between those factors can trigger an 'upward spiral of positive emotions' (see Fredrickson \& Joiner, 2002) and eventually lead to Human Flourishing. For example, attending a workshop to escape the negativity of prison can promote a new set of skills and competencies as well as finding a sense of purpose and pride. This positivity can provide the emotional resources requested to cope with poor prison conditions, while increasing the likelihood of experiencing further positive emotions and Flourish. However, where negative experiences of imprisonment prevail, an opposite downward spiral can develop, leading to despair, and in the worst cases self-harm and suicide. One of the aims of this research is to understand the way the social environment and personal factors can prevent some of the negative outcomes of imprisonment.

\section{Normalisation - prison food}

In order to improve conditions and make human flourishing within prison more likely, it is important for the prison experience to be as normalised (i.e. as close to life outside) as possible. The contribution by Vanhouche examined an attempt to normalise food consumption within prisons, and the factors that impacted on this initiative.

In 2005, the Belgian government accepted a Prison Act that states prisoners' rights and duties as well as the goals of imprisonment. One of the leading principles of this prison act is "normalisation" which means that life inside prison should look as much as possible to the positive aspects of life in outside society. However, ten years after the acceptance of this principle, it seems that it is poorly introduced in most prisons. Therefore, Vanhouche questions the reasons for this poor implementation by comparing prisons. Some prisons, do not introduce this principle while others manage to gradually normalise their regime. Normalisation can be achieved through several aspects of prison life, Vanhouche and colleagues focus on one such aspect: foodways.

The extent to which foodways are normalised, give us an insight in how practitioners implement this principle. This can go from poorly normalised regimes where pre-prepared meals are served to prisoners in their cells to self-catering which allows prisoners to choose and prepare their own meals. The research was conducted in five prisons. In four prisons, situated on Belgian territory, inmates 
received pre-prepared meals in their cells. In total, 40 interviews were conducted and two weeks of observations in each prison. The fifth prison is situated on Dutch territory but is currently rented by Belgium. In this institution, the Belgian prison act is executed by Dutch prison officers. When the co-operation between Belgium and the Netherlands started in 2010, prisoners received ready-made meals. However, due to strong criticism from prisoners, a self-catering system was introduced. In this institution, seventy interviews were conducted and three months of observations.

The interviews and informal talks with staff and prisoners revealed that underlying ideas of imprisonment can highly influence these catering systems. In the prison where self-catering was introduced, prison officers supported prisoners' self-reliance, human dignity and normalisation, principles that could be put into practice thanks to dynamic security. In the other four prisons, staff's focus on static security measures impedes normalisation. Secondly, the presence of prisoner assemblies created the opportunity for prisoners to complain and insist on the introduction of a self-catering system. Thirdly, the particularity of the multicultural prison population in the fifth prison urged inmates' demand for a selfcatering system. This system allowed them to cook according to their cultural habits. Finally, the prison architecture, presence of kitchens on the wings and absence of prison overcrowding created a relative positive material context in the fifth prison which made normalisation possible.

\section{Prison architecture}

It is clear from the above that prison architecture has a major role to play in the normalisation of prison life. However, in the following contribution, Jewkes, Moran and Turner discussed how the flexibility of this architecture is limited by the way in which modern prisons are built. Throughout the history of imprisonment, the use of cellular confinement has been instrumental in shaping the organisation of prison as a space of reform, separation, deterrence and isolation. As Helen Johnston highlights, "although now often occupied by more than one prisoner, the cell has remained architecturally the most significant space in the prison." (2010: 14). Today, we are witnessing a 'modernising' of the penal estate across the UK where 'new for old' policies have seen the closure of inefficient prisons and their replacement with larger, fit-for-purpose establishments. The Ministry of Justice, alongside other UK public sector procurers, is moving towards the utilisation of Building Information Modelling (BIM) to inform building design. This has undoubtedly changed the way that prisons are designed, built and experienced. BIM is a process involving the development of a digital blueprint, is often 
also used for the design of new prisons, which, in practice means producing a three-dimensional geometric model of a building at the design stage, incorporating all physical structures and services (walls, floors, roof, plumbing, wiring, apertures, ventilation etc.). This then enables the off-site prefabrication of prison components and the replication of standard designs across the prison estate. The prison cell is at the very heart of this process. The cell units piece together like Lego blocks, creating arguably enhanced, standard conditions of security, infrastructure, sanitation and furnishing for every prisoner. Under this model, each prisoner will have access to an in-cell toilet and shower, for example.

Jewkes, Moran and Turner focused upon new-build prisons in the UK and Scandinavia, and interrogated the contemporary prison cell, focusing specifically upon the practices and performances that comprise the lived experiences of this space for the individuals incarcerated within them. Their research reveals that the design and build process raises a number of challenging questions for the contemporary landscape of incarceration. How does the lived experience of carceral space manifest itself for prisoners; beneath the prescribed benefits for policy makers of cost, standardisation and security? Yet, what happens when we replicate the same cell across the estate? Cells have become the most easily replicable part of the prison estate. They are firmly embedded into the library of BIM parts, so much so that some architects have admitted that they no longer spend time focussing on these areas of the prison - instead hoping to win bids with unique configurations of houseblocks or innovative technological advances to reduce staffing or heating costs, for example. Yet, we must pay careful attention to the significance of individual human bodies in the replication of cell space; particularly in view of the new designs of new prisons, which result in an increase in the number of hours that a prisoner may spend in their cell; the number of activities that take place in it; and services that operate from the individual cell. The cell has become somewhat taken for granted - when it is clearly one of the most complex and significant elements of life in prison.

\section{Digital technologies in prisons}

A powerful innovation that would allow prisoners to live lives closer to those outside would be to allow digital technology to penetrate prison life in the same way as it does life outside. However, Knight shows that there are significant obstacles to such innovation. The emergence of digital technologies in everyday life has accelerated at an unprecedented speed. However, it has not evolved at the same speed or as abundantly in our prisons. Prisons are 'communication poor' environments (Knight, 2016) whereby prisoners' access to multiple modes of 
communication (situated and mediated) are strictly controlled and regulated. These kinds of incapacitation have significant deprivations on both the prisoner and prison (Knight 2016; Jewkes and Johnston, 2009). Knight considers how digital technologies are both conceived and realised by prison organisations.

These organizational transformations highlight important differences between those prisons that are willing to conceive innovation and those that can't be or aren't willing. Transformational willingness takes place in largely 'active' organisations as opposed to 'passive'. This is further supported by the fact that some organisations, in this case prisons, have more capability and capacity to introduce new ideas or ways of working than others. The innovative organisation is able to make these introductions through a process of 'routinization' (Schumpeter, 1942). This is further assisted, according to organizational behaviourists by short and open feedback on trials and pilots as well as significant investment in research and design development (Coriat et al., 2002). It is these qualities that seem to mirror the discreet pockets of recent digital development across different carceral jurisdictions. It is possible to conceptualize prisons in two ways: Type $A$ institutions - these '... generally operate through 'agencies' in charge of the definition of the set of rules which the agents have to obey' (Coriat et al., 2002). This resembles the public prison whereby policy and practice are orchestrated by the overarching state departments. The Type B institutions usually operate under contract and are able to '.. give birth to entirely new fields of action or new environments' (Coriat et al., 2002). From a British perspective the introduction of incell telephony and self-service kiosks to enable prisoners to manage their activities, visits, requests, shopping has been led by privately owned prisons (Independent, 2013). In other countries like Belgium, PrisonCloud enables prisoners to have access to digital single platforms where they can access self-service, desktop packages, telephony, e-learning, their legal files and entertainment like television and films (Knight, 2015). Whilst public prisons- Type A organisations have not followed these innovations with the same vigour, there is some desire to progress digitization of the penal system. PrisonCloud will be rolled out nationally across the Belgian prison estate (Het Newsbled, 2016). As with the Belgian model The Netherlands are currently developing similar models for their prisons.

This dichotomy of institutions is not just polarized by public and/or private ownership. Their cultural and normative values which enable and even disable them to take advantage of innovation. Organisational reputation is enhanced by promoting competency, ICT literacy and measures to overcome risks or cyber threats. Penal debates about the ways in which prisoners should be managed and treated, resulting in powerful forms of resistance. The punitive drivers contribute 
towards further amplification of digital technologies as luxury items and prisoners are underserving and less eligible to access these. Moreover concerns about security and potential access to the internet mean they could reach victims and witnesses as well as continue criminal activities on-line and thus deceive their keepers. Added to this are concerns about cost to the public purse- initial installation is expensive and disruptive. The risk is that prisoners' access to digital technology to enhance their chances of rehabilitation and progress through their prison sentences is stalled largely by nervousness- the fear of getting it wrong is powerful. The need to eliminate uncertainties is echoed in Britain's Coates Review (2016) recommending that digital investment for education purposes is secured. The inevitability of digitization of our prisons is becoming clear, yet the rate and speed at which this will happen are dependent on organisational and cultural capabilities.

\section{Order and control in prison}

In the following contribution, Butler examined how positive initiatives within prison, here a parenting programme, are undermined by the context in which they are delivered, showing that piecemeal change is not enough.

Butler explored the importance of prison visits. Research indicates that those who do not receive visits while imprisoned are more likely to be found guilty of engaging in officially recorded prison misconduct (Cochran, 2012). However, this relationship is not straightforward as the effect of prison visitation varies depending on the characteristics of the visitor and those being visited, the timing of visits, their frequency and the visiting experience (Cochran \& Mears, 2013; Siennick et al., 2013). Butler sought to enhance our understanding of why the influence of visitation on misconduct varies. She highlights how the ability of prison visits to discourage misconduct can change over time and offers some explanations for why this happens.

Using a combination of in-depth semi-structured interviews $(\mathrm{N}=42)$ and observations, Butler's research examined how receiving special four hour family visits as part of a parenting programme initially motivated adherence to prison rules, but two months later no longer discouraged prison misconduct (for a more detailed account of the research see Butler, Hayes, Devaney \& Percy, 2015).

The findings indicated that while the family visits continued to be viewed positively by those imprisoned, dissatisfaction with wider situational factors outweighed the potential ability of the visits to act as an incentive for avoiding involvement in misconduct. Irritation at regime delivery failures and feelings of procedural injustice created an atmosphere of discontent and anger. This discon- 
tent and anger led the imprisoned fathers to suggest engaging in an incident of collective protest. Reputational concerns amongst the imprisoned fathers regarding how their peers would view them if they did not participate, lead many to engage in this behaviour despite their concerns about losing their family visits. During the incident, both staff and those imprisoned were reluctant to lose power to each other, as they were worried about how this would be viewed by others. This resulted in more tense verbal interactions and a decision by the senior prison official at that time to formally charge the fathers with misconduct rather than attempt to resolve the matter informally.

These findings suggest that in order to understand the links between visitation and misconduct, studies must go beyond the visiting experience, type of visitor and characteristics of those being visited, to also examine the prison regime, power dynamics, perceptions of procedural justice, reputational concerns of both those imprisoned and staff as well as the use of discretion in deciding when to formally charge someone with misconduct. Accordingly, the study of prison visitation and its possible links to prison misconduct may be better understood when situated within the wider prison context and experience of imprisonment.

\section{Having trustful relationships in detention and detainees' mental health and aggression}

While Butler's study focused on the importance of receiving visits from the outside world, Kreager, Palmen, Dirkzwager and Nieuwbeerta (2016) focused on having social ties with fellow inmates and how this affects prisoners' mental health and their aggressive behaviour.

Prior research has linked weak social ties to poor mental and physical health, like suicide, depression, cardiovascular diseases and high blood pressure (e.g. Durkheim, 1897/1951; Callaghan \& Morrissey, 1993). Although this literature generally shows strong health benefits of social integration, it is clear that not all relationships are equal and some may even have adverse health consequences. For instance, it has been demonstrated that social ties may also promote healthrisk behaviours, like substance use, crime and violence (Leung, Toumbourou \& Hemphill, 2014; Weerman, 2011). Therefore, the association between social integration and health may vary across different social and relationship contexts. One specific social context is detention, in which individuals are involuntarily put together with high-risk individuals. This raises the question whether social relationships within the correctional context are also beneficial for prisoners' health and well-being. Kreager, Palmen, Dirkzwager and Nieuwbeerta (2016) examined whether social integration in detention - measured as having trustful relationships 
with fellow inmates - was associated with both aggression and mental health of men detained in pre-trial detention. To examine these relationships, longitudinal data were used from 467 Dutch male prisoners who were held in pre-trial detention for about three months.

Data were used from the Prison Project, a nationwide and longitudinal study in the Netherlands on the effects of detention on the further life course of offenders (Dirkzwager, Nieuwbeerta \& Van der Laan, 2015). For this study, data were used from the first two measurements, in which the inmates were questioned three weeks and three months after their arrival in pre-trial detention (for more information, see Kreager et al., 2016). The key measures for this study included (a) having trustful relationships with at least one other inmate three months after arrival in pre-trial detention; (b) prisoners' self-reported aggressive behaviour towards other inmates during their first three months of detention, and (c) prisoners' self-reported mental health problems three months after their arrival in detention.

Respondents with and without at least one trusted fellow inmate did not differ with respect to their level of aggressive behaviour towards other inmates. However, having trusting relationships with other inmates was significantly associated with mental health problems. Prisoners, who trusted at least one other inmate, reported a higher level of mental health problems after three months. Furthermore, prisoners who were visited by friends from the outside world and prisoners sharing a cell reported fewer mental health problems.

It turned out that the men in this study who placed trust in their fellow inmates seemed to put themselves at higher risk of mental health problems and were no more protected from aggression than prisoners without such trusting ties. This study adds to a small body of literature suggesting that social integration within correctional settings may not operate in the same way as it does in the general population, and in some situations may contribute to adverse mental health outcomes (Lindquist, 2000; Rivlin et al., 2013). In some situations, "doing your own time" may benefit prisoners' health and does not seem to result in more aggression and violence. Of course, it must be realized that the present study examined social integration and mental health over a three-month detention period. Not being able to establish meaningful relationships over an extended period may increase loneliness and mental health problems (Shalev, 2011). Under these circumstances establishing at least one trusting relationship could substantially increase prisoners' mental health.

From the above contributions it is clear that the conditions of confinement, including social relationships during imprisonment, will have at least some impact 
on post-prison experiences. Those who flourish in prison are likely to do better than those who respond to overcrowding and bad conditions by retreating into their own subcultural norms, or perhaps even trusting one other inmate. Prisoners with fewer mental health problems are probably more able to deal with the challenges of a successful re-entry (e.g. finding a job, recidivism). Moreover, having access to technology and living in a cell that could be construed as a 'living room' is also likely to better prepare people for release.

\section{Procedural justice in prison and reoffending after release}

In a contribution examining the link between within-prison conditions and postprison outcomes, Beijersbergen explored reoffending after release from prison in the Netherlands.

Reoffending rates after release from prison are high in most Western countries (e.g. Ministry of Justice, 2015; Nilsson, 2003; Wartna, et al., 2011). Clearly, more knowledge is necessary on the effects of imprisonment to reduce these high reoffending rates. As certain aspects of prison life are directly under the control of policy makers and correctional administrations, knowledge on how such circumstances affect post-release offending behavior may be valuable to effective crimecontrol and successful prisoner reentry (Chen \& Shapiro, 2007).

One aspect of prison life that may potentially affect prisoners' reoffending behavior refers to the extent to which prisoners feel treated fairly and respectfully. This notion is central to procedural justice theories, which argue that people will be more likely to comply with the law when they feel treated in a procedurally just manner by actors who enforce the law (e.g. Leventhal, 1980; Tyler, 1990). Applied to the correctional setting, procedural justice theories suggest that an unfair and disrespectful treatment of prisoners wil result in resistance and misbehavior both during and after imprisonment.

The proces-based model of regulation by Tyler (2003) proposes that this relationship between procedural justice and compliance is explained by legitimacy, i.e. the belief that authorities and institutions are appropriate and just, and, therefore, are entitled to be obeyed (Tyler, 1990, 1997). According to Tyler's model, people who feel treated fairly and respectfully by criminal justice authorities, will view these authorities and their rules as more legitimate, and, subsequently, will be more likely to obey the law and rules of these authorities.

Prior research, in general, has supported procedural justice theories, including the mediating effect of legitimacy (e.g. Reisig \& Mesko, 2009; Tyler, 1990; Tyler \& Jackson, 2014). However, research among offender populations has been limited. At present, it is unknown whether or not a procedurally just treatment of 
prisoners during imprisonment can reduce postprison reoffending rates, and whether or not this relationship is mediated by legitimacy.

Beijersbergen examined (a) whether prisoners' procedural justice perceptions during imprisonment influenced their postrelease offending behavior, and (b) whether the relationship between procedural justice and reoffending was mediated by prisoners' perceived legitimacy of the criminal justice system. Associations were explored with survey and registered conviction data of 1.241 Dutch prisoners from the Prison Project. To measure procedural justice, prisoners were asked during imprisonment to what extent they felt treated fairly and respectfullly by correctional staff. In line with prior research, legitimacy was operationalized in two ways: prisoners were asked to what extent they supported the criminal justice authorities and to what extent they felt obligated to obey the law. Reoffending was measured using registered conviction data.

Results showed that, although the effect was small, prisoners who felt treated in a procedurally just manner during imprisonment were less likely to be reconvicted in the 18 months after release. No evidence was found for a mediating role of legitimacy. Although procedural justice was related to both measures of legitimacy, neither measure of legitimacy had a significant effect on whether or not a prisoner was reconvicted after release.

The results of this study are relevant for correctional policy and practice, and suggest that correctional authorities can contribute to lower reoffending rates by treating prisoners fairly and respectfully during imprisonment (Beijersbergen, Dirkzwager \& Nieuwbeerta, 2016).

\section{The meaning of persistent short-term imprisonment}

Whether or not what happens in prison will have an effect on future behaviour will depend to a large extent on how the period of incarceration is given meaning by those who undergo it (Schinkel, 2014). Schinkel's contribution explored how people with experience of multiple short-term prison sentences made sense of this experience, both as an accumulation of punishment and in the context of their wider lives. Life history interviews were carried out with 22 men and 15 women, many of whom were interviewed in prison.

Four different patterns of meaning were identified. The first, persistent disruption, was one common amongst those with some resources, like family or accommodation, outside. Their repeated prison sentences led to either the immediate or the slow loss of these resources. Houses and flats were usually lost right away (in the UK Housing Benefit is stopped if someone is expecting to be in prison for more than 13 weeks, and only very few managed to set up a payment 
plan with their housing provider), while the erosion of relationships tended to be more gradual. However, the repeated nature of their prison sentences meant that these people's lives were put on a cumulatively less insecure footing. For example, Brian had just entered a new relationship, and was worried that his current sentence could both harm the relationship and an unborn child, plus lead to further offending.

"I'm worried in case I do not get out of here. What is going to happen to her and the bairn [child] that she is pregnant with. And if she goes back on the drugs while I am in here, eh? Because I do not want to get back out there to her being back on that stuff. And while she is pregnant especially. It is horrible. I will go after whoever gave her it." (Brian)

The pattern of intermittent freedom was one experienced by those whose lives were mostly lived inside the prison. Periods outside for them were a temporary window of time in which to have as much fun as possible.

"If you are out six months, back in, out ... you look at it as 'I am getting out for a holiday'. You are going out to binge drink, take drugs, THEN come back.” (Tyler)

Several participants described using prison as a (poor) resource. They either offended on purpose, or they welcomed their prison sentence, because it was the only support that was available to them. Most often, this was because prison could provide housing or some form of drug rehabilitation immediately, for which there were long waiting lists in the community.

"But there was times when I was going out and I was just getting no help at all ... even when I was trying tae get ma life sorted. So instead ae trying that wee bit more, I was just coming back in. On purpose." (Alex)

Finally, for some prison had no meaning in itself, but came as a consequence of other problems (such as drug addiction) or events (such as a traumatic car crash).

"There has not been any impact. The only impact has been the drugs, that I have lost ma family and that through it. Just ... it is the drugs that have been the impact, not the jail sentences." (Savannah)

For the participants, the meaning held by their repeated imprisonment changed over the course of their lives. For example, prison could only be a persistent disruption for so long before all resources were lost and a shift to another meaning 
occurred. Almost all participants regretted the amount of time they had spent in prison, though, seeing their time inside as 'wasted time', and feeling like they had lost valuable time and missed important events outside. They wished that imprisonment was either a more effective deterrent or more rehabilitative, so that they would have stopped offending sooner and their lives could have been different.

\section{Final remarks}

In this paper a selection of timely prison research from a variety of European countries, each with their own specific prison context, is presented. The contributions included here highlight a range of opportunities to improve the conditions of confinement and rehabilitative efforts, and to reduce recidivism after release from prison. While countries in Eastern Europe struggle with a governmentality gap between political rhetoric and practice on the ground (Dirga; Pricopie and Damboeanu), Western European countries face impediments to the normalisation of prison life, including possibilities for self-catering for prisoners (Vanhouche), the restrictive environment within which any rehabilitation has to take place (Butler), the way prisons are built (Jewkes, Moran and Turner) and structural opposition to innovation, such as digital technology (Knight). How prisoners adapt and give meaning to their sentence is not only determined by prison conditions, as this will also depend on their life outside (Schinkel). However, Tomczak rightly argues for a better response to prison suicides, including a clear examination of any link with the specific prison conditions experienced, so that lessons can be learned and conditions changed in order to reduce this most negative of outcomes in the future. Poor conditions of confinement and treatment can also give rise to collective opposition, especially among groups of prisoners with a shared identity (Wahidin). Tartarini found that a few people manage to flourish in prison - while this was mostly attributed to personal characteristics, some of these depended on meaningful activities being available (or possible) within prison. Finally, Beijersbergen showed that fair and respectful treatment of prisoners during imprisonment is linked to lower reoffending rates after release.

This multifaceted perspective on current and past imprisonment in Europe has been made possible through prison scholars coming together in order to share their work and explore the syntheses between different research projects. This provides points for important new research questions (and possibly projects). Of particular interest in this paper are the juxtapositions between different findings and locations. For example, while in the Netherlands a trustful relationship with other prisoners had (slightly) negative consequences for mental health (Kreager, Palmen, Dirkzwager and Nieuwbeerta, 2016), the obverse might be true in coun- 
tries where prison conditions are more challenging, and where 'doing your own sentence' might condemn you to even more squalid conditions. Do more positive conditions always lead to more positive outcomes, or might the collective resistance described by Wahidin also have positive consequences for prisoners' mental health and post-release outcomes? International comparative research might help to further enhance our knowledge on the conditions of confinement and their impact on prisoners' adjustment both in and after prison, in different correctional and cultural contexts. The link between what imprisonment looks and feels like and post-release outcomes remains an under-researched and challenging research area, but one that needs addressing from as wide a variety of perspectives as possible.

\section{Notes}

1. Linda Kjær Minke, University of Southern Denmark, Department of Law, Odense, Denmark; Marguerite Schinkel, University of Glasgow, Glasgow, Scotland; Karin Beijersbergen, Ministry of Security and Justice, Research and Documentation Centre (WODC), Crime, Law Enforcement and Sanctions Division (CRS), Den Hague, The Netherlands; Cristina Damboeanu, Institute of Sociology, Bucharest, Romania; Lukáš Dirga, Department of sociology, andragogy and cultural anthropology, Palacký University Olomouc, Czech Republic; Anja Dirkzwager, Netherlands Institute for the Study of Crime and Law Enforcement (NSCR), Amsterdam, The Netherlands; Yvonne Jewkes, School of Applied Social Science, University of Brighton, UK; Victoria Knight, De Montfort University, Leicester, UK; Dominique Moran, University of Birmingham, UK; Hanneke Palmen, Leiden University, Institute of Criminal Law and Criminology, The Netherlands; Valentina Pricopie, Institute of Sociology, Bucharest, Romania; Fabio Tartarini, University of Wolverhampton, UK; Philippa Tomczak, Centre for Criminogical Research, University of Sheffield, UK; Jennifer Turner, School of Applied Social Science, University of Brighton, UK; An-Sofie Vanhouche, Faculty of Law and Criminology - Department Criminology Crime and Society Research Group - Penality and Society,Vrije Universiteit, Brussels, Belgium; Azrini Wahidin, Sociology Division, School of Social Sciences, College of Business, Law \& Social Sciences Nottingham Trent University, UK.

2. Layer: Total prison population and Europe as region.

3. Layer: Occupancy level and Europe as region.

4. Layer: Pre-trail detainees and Europe as region.

5. Layer: Foreign prisoners and Europe as region.

6. Despite a slight recovery of Czech prison research in recent years (for example Dirga, Hasmanová-Marhánková 2014; Dirga, Lochmannová, Juříček 2015; Dirga 2016), the issue of human rights in the Czech prison system continues to be ignored and is still not given sufficient attention.

7. See, for example, the prison law 254/2013 (and its predecessor, the prison law 275/2006), but also the National Strategy of Prisoner Reintegration 2015-2019. 
8. National Administration of Prisons (2016) Prison Accommodation Capacity and Prison Population on 14 June 2016. Available on www.anp.gov.ro

\section{References}

Bilby, C., Caulfield, L. \& Ridley, L., (2013). Re-imagining futures: exploring arts interventions and the process of desistance,

Beijersbergen, K.A., Dirkzwager, A.J.E. \& Nieuwbeerta, P. (2015). Reoffending after release: Does procedural justice matter during imprisonment? Criminal Justice and Behavior, 43(1), 63-82.

Butler, M., Hayes, D., Devaney, J. \& Percy, A. (2016) Strengthening family relations? A review of the Families Matter programme at Maghaberry Prison. Belfast: Barnardo's NI.

Callaghan, P. \& Morrissey, J. (1993). Social support and health: A review. Journal of Advanced Nursing, 18(2), 203-210.

Chen, M.K., \& Shapiro, J.M. (2007). Do harsher prison conditions reduce recidivism? A discontinuity-based approach. American Law and Economic Review, 9, 1-29.

Clemmer, D. (1958). The prison community. New York: Rinehart \& Co

Cochran, J.C. (2012). The ties that bind or the ties that break: Examining the relationship between visitation and prisoner misconduct. Journal of Criminal Justice, 40(5), 433-440. doi:10.1016/j.jcrimjus.2012.06.001.

Cochran, J.C., \& Mears, D.P. (2013). Social isolation and inmate behavior: A conceptual framework for theorizing prison visitation and guiding and assessing research. Journal of Criminal Justice, 41(4), 252-261. doi:10.1016/j.jcrimjus.2013.05.001.

Cohen, S. \& Taylor, L., (1972). Psychological survival: The experience of long-term imprisonment Penguin., Middlesex: Penguin Books Ltd.

Cohn, M.A. \& Fredrickson, B.L., (2009). Broaden-and-Build Theory of Positive Emotions. In S. Lopez, ed. The encyclopedia of positive psychology. Wiley-Blackwell, 105-110.

Coates, S. (2016) Unlocking Potential: A review of education in prison Ministry of Justice https:/www.gov.uk/government/uploads/system/uploads/attachment_data/file/524013/educa tion-review-report.pdf accessed 21.5.16

Coriat, B. and Weinstein, O. (2002). Organizations, firms and institutions in the generation of innovation. Research policy, 31(2), 273-290.

Cox, A. \& Gelsthorpe, L. (2009). Creative encounters: whatever happened to the arts in prisons? In L.K. Cheliotis, ed. The arts of imprisonment. Control, resistance and empowerment. Farnham, Surrey: Ashgate Publishing Limited, 257-176.

Crewe B. (2011). Depth, Weight, Tightness: Revisiting the Pains of Imprisonment. Punishment and Society, 13(5), 509-529.

Dirga, L. (2016). Možnosti a úskalí vězeňské etnografie: metodologická reflexe využití vězeňské etnografie $\mathrm{v}$ českém kontextu (Possibilities and pitfalls of prison ethnography: methodological reflection on the use of prison ethnography in the Czech context). Česká kriminologie/Czech Criminology 2 (1), 1-12.

Dirga, L., A. Lochmannova; P. Juricek. (2015). The Structure of the Inmate Population in Czech Prisons. Sociológia/Slovak Sociological Review 47 (6), 559-578. 
Dirga, L., J. Hasmanova -Marhankova (2014). Nejasné vztahy moci - vězení očima českých dozorců. (Prison as a Place of Ambiguous Power Relations: The Perspectives of Czech Prison Guards) Sociologický časopis/Czech Sociological Review 50 (1), 83-105.

Dirkzwager, A.J.E., Nieuwbeerta, P. \& Laan, P.H. van der (2015). The Prison Project: A longitudinal study on the effects of imprisonment in the Netherlands. EUROPRIS Newsletter, November 2015.

Durkheim, E. (1951). Suicide: A Study in sociology. The Free Press, New York, NY. Original work published 1897.

Fredrickson, B.L. \& Joiner, T. (2002). Positive emotions trigger upward spirals toward emotional well-being. Psychological science, 13(2), 172-175.

Goffman, E. (1961). Asylums: Essays on the soocial situatioon of mental patients and other inmates. Chicago: Aldin.

Het Newsbled (2016). Alle Belgische gevangenen krijgen digitale tvhttp:/www.nieuwsblad.be/ cnt/dmf20160107_02053537 accessed 20.1.16

Howard League (2016). The cost of prison suicide. Research briefing.

Inquest (2012). Learning from Death in Custody Inquests: A New Framework for Action and Accountability.

International Centre for Prison Studies (2016) World Prison Brief. Available at www.prisonstudies.org/world-prison-brief (accessed 14 September 2016).

Jewkes, Y. (2013). Captive Audience. Routledge.

Jewkes, Y. and Johnston, H. (2009). Cavemen in an Era of Speed-of-Light Technology: Historical and Contemporary Perspectives on Communication within Prisons. The Howard Journal of Criminal Justice, 48(2), 132-143

Johnston, H. (2010). The Cell: Separation, isolation and space in the architecture of the birth of the prison. Prison Service Journal Special Issue: Prison Space 187, 9-14.

Knight, V. (2016). Remote Control: Television in Prison Palgrave Macmillian

Knight, V. (2015). Some Observations on the Digital Landscape of Prisons Today Prison Service Journal July 2015 No 220, 3-9.

Kreager, D.A., Palmen, H., Dirkzwager, A.J.E. \& Nieuwbeerta, P. (2016). Doing your own time: Peer integration, aggression and mental health in Dutch male detainment facilities. Social Science \& Medicine, 151, 92-99.

Leung, R.K., Toumbourou, J.W. \& Hemphill, S.A. (2014). The effect of peer influence and selection processes on adolescent alcohol use: A systematic review of longitudinal studies. Health Psychology Review, 8(4), 426-457.

Leventhal, G.S. (1980). What should be done with equity theory? New approaches to the study of fairness in social relationships. In K. Gergen (Ed.), Social exchange: Advances in theory and research, 27-55. New York, NY: Plenum Press.

Liebling, A. (2004). Prisons and their Moral Performance. Oxford University Press.

Liebling, A. (1999). Prison suicide and prisoner coping. Crime and Justice, 26, 283-359.

Lindquist, C.H. (2000). Social integration and mental well-being among jail inmates. Sociological Forum, 15(3), 431-455.

Minke, K.L. \& Smoyer, A. (forthcoming). Prison Food in Denmark: Normal Responsibility or Ethnocentric Imaginations. Scharff Smith, P. \& Ugelvik, T. (forthcoming), Scandinavian Penal History, Culture and Prison Practice. Springer, UK. 
Ministry of Justice (MoJ) (2014). Safety in Custody Statistics England and Wales: Update to March 2014. Statistics Bulletin: MoJ

Ministry of Justice (2015). Proven re-offending statistics quarterly bulletin: April 2012 to March 2013. London, UK.

Ministry of Justice (2016). Safety in Custody Statistics England and Wales: Deaths in prison custody to March 2016, Assaults and Self-harm to December 2015. London: MoJ

Nilsson, A. (2003). Living conditions, social exclusion and recidivism among prison inmates. Journal of Scandinavian Studies in Criminology and Crime Prevention, 4, 57-83.

Pratt, J. and Eriksson, A. (2013) Contrasts in Punishment: An explanation of Anglophone excess and Nordic exceptionalism. London: Routledge.

Prison and Probation Ombudsman (2015). Annual Report 2014-2015.

Rasch, B.E. (2011). Behavioural Consequences of Restrictions on Plenary Access: Parliamentary Questions in the Norwegian Storting. The Journal of Legislative Studies, 17, 382-393.

Reisig, M.D., \& Mesko, G. (2009). Procedural justice, legitimacy and prisoner misconduct. Psychology, Crime \& Law, 15, 41-59.

Rivlin, A., Hawton, K., Marzano, L., Fazel, S. (2013). Psychosocial characteristics and social networks of suicidal prisoners: Towards a model of suicidal behaviour in detention. PLOS ONE, 8, doi:10.1371/journal.pone.0068944.

Schinkel, M. (2014). Being Imprisoned: Punishment, Adaptation and Desistance. Houndmills: Palgrave Macmillan.

Schumpeter, J.A. (1942). Capitalism, Socialism and Democracy, $5^{\text {th }}$ ed., London, Allen\&Unwin, 1976.

Seligman, M.E.P. (2011). Flourish: A New Understanding of Happiness, Well-being-and how to Achieve Them, St Ives: Clays LTD.

Shalev, S. (2011). Solitary confinement and supermax prison: A human rights and ethical analysis. Journal of Forensic Psychology Practice, 11, 151-183.

Siennick, S.E., Mears, D.P., \& Bales, W.D. (2013). Here and gone: Anticipation and separation effects of prison visits on inmate infractions. Journal of Research in Crime and Delinquency, 50(3), 417-444. doi:10.1177/0022427812449470.

Sykes G. [1958] (2007). The Society of Captives. A Study of a Maximum Security Prison. Princeton, N.J.: Princeton University Press.

The Czech Prison Service (2014). Východiska a záměry nové koncepce vězeňství v České republice (Basis and Plans of New Czech Prison System Conceptual Framework). Praha: Vězeňská služba ČR, Generální ředitelství (The Czech Prison Service, Headquarters).

The Czech Prison Service (2005). Koncepce rozvoje českého vězeňství do roku 2015 (The Czech Prison System Conceptual Framework until 2015). Praha: Vězeňská služba ČR, Generální ředitelství (The Czech Prison Service, Headquarters).

The Independent (2016). Prisoners given in-cell phones and screens http://www.independent.co. $\mathrm{uk} /$ news/uk/home-news/prisoners-given-in-cell-phones-and-screens-9000003.html accessed 24.5.16

The Ministry of Justice of the Czech Republic (2016). Koncepce vězeňství do roku 2025 (Prison System Conceptual Framework until 2025). Praha: The Ministry of Justice of the Czech Republic. 
The Scottish Government (2014). The Digital Strategy for Justice in Scotland http://www.gov. scot/Publications/2014/08/5429/0 accessed 21.5.16

Treimane, L. (2011). Analyzing parliamentary discourse: systemic functional perspective. Kalbotyra, 63 (3), 78-94.

Toch, H. (1977). Living in prison: The ecology of survival, New York.

Tyler, T.R. (1990). Why people obey the law. New Haven, CT: Yale University Press.

Tyler, T.R. (1997). The psychology of legitimacy: A relational perspective on voluntary deference to authorities. Personality and Social Psychology Review, 1, 323-345.

Tyler, T.R. (2003). Procedural justice, legitimacy, and the effective rule of law. In M. Tonry (Ed.), Crime and justice: A review of research, 30, 431-505. Chicago, IL: University of Chicago Press.

Tyler, T.R. (2009). Legitimacy and criminal justice: The benefits of self-regulation. Ohio State Journal of Criminal Justice, 7, 307-359.

Tyler, T.R., \& Jackson, J. (2014). Popular legitimacy and the exercise of legal authority: Motivating compliance, cooperation, and engagement. Psychology, Public Policy, and Law, 20, 78-95.

Wacquant, L. (1999). Suitable enemies: Foreigners and immigrants in the prisons of Europe. Punishment \& Society, 1(2), 215-222.

Wartna, B.S.J., Tollenaar, N., Blom, M., Alma, S.M., Bregman, I.M., Essers, A.A.M., \& Van Straalen, E.K. (2011). Recidivism report 2002-2008: Trends in the reconviction rate of Dutch offenders. The Hague, The Netherlands: Research and Documentation Centre of Ministry of Security and Justice.

Weerman, F.M. (2011). Delinquent peers in context: A longitudinal network analysis of selection and influence effects. Criminology, 49(1), 253-286. 